\title{
Serum levels of MMP-11 correlate with clinical outcome in Chinese patients with advanced gastric adenocarcinoma
}

\author{
Dong Yan ${ }^{1 *}$, Hong Dai ${ }^{1}$ and Jin-Wei Liu²
}

\begin{abstract}
Background: The aim of the present study was to investigate the association between serum levels of matrix metalloproteinase 11 (MMP-11) and responses to front-line chemotherapy and prognosis in advanced unresectable gastric adenocarcinoma.

Methods: Clinical data concerning 86 patients with advanced gastric adenocarcinoma (stages III c to IV), treated in Beijing Chao-Yang Hospital from 2005 to 2009, were reviewed retrospectively. Adenocarcinoma was confirmed by pathology and patients received 5-fluorouracil-based front-line combination chemotherapy with third generation chemotherapeutic agents including paclitaxel, docetaxel and oxaliplatin. The regimen was repeated every two to three weeks, and the first evaluation was carried out after three cycles. The median cycle of chemotherapy was 6 (ranging from three to twelve cycles). Serum MMP-11 protein from the 86 patients was examined using enzymelinked-immunosorbent-assay (ELISA) prior to chemotherapy and after three cycles of chemotherapy. Serum samples from healthy individuals were used as controls.
\end{abstract}

Results: The response rate (RR, complete response plus partial response) to chemotherapy in the 86 patients was 44.2\% (38/86). The median TTP (time to progression) and overall survival (OS) in patients who responded to chemotherapy were 6.0 and 10.0 months, respectively. The response rate to chemotherapy in patients with high levels of serum MMP-11 (42.9\%; 9/21) was similar to that in patients with low levels $(44.6 \% ; 29 / 65)(P=0.935)$. Patients with low serum levels of MMP-11 had a higher median survival time and 1-year survival rate than those with high levels (11 months vs. 8 months, $50.2 \%$ vs. $21.7 \%, P=0.017$ ), although the TTP was comparable in all patients, irrespective of serum MMP-11 level $(P=0.178)$. Serum MMP-11 levels were correlated with lymph node metastasis $(P=0.006)$. Cox multivariate regression analysis demonstrated that the serum level of MMP-11 was an independent prognostic factor for patients presenting with advanced gastric carcinoma.

Conclusions: Serum levels of MMP-11 in Chinese patients with advanced gastric carcinoma were not associated with the response to front-line chemotherapy, but could play an important role in lymph node metastasis and prognosis.

Keywords: advanced gastric adenocarcinoma Matrix metalloproteinase 11, overall survival, prognosis, TTP

\section{Background}

Gastric cancer (GC) is the second most common cancer world-wide, and the third leading cause of cancerrelated deaths in China. Although the most effective treatment for $\mathrm{GC}$ is surgical resection, approximately $70 \%$ of patients presenting with GC have a locally

\footnotetext{
* Correspondence: yd15yt88@163.com

'Department of Oncology, Beijing Chao-Yang Hospital affiliated with Capital Medical University, 8\# Baijiazhuang Road, Beijing, China

Full list of author information is available at the end of the article
}

advanced and metastatic disease at the time of initial diagnosis, precluding the option of surgical resection [1]. Therefore, systemic cytotoxic chemotherapy is a major therapeutic strategy for advanced gastric carcinoma. The combination of third generation chemotherapeutic agents including paclitaxel, docetaxel and oxaliplatin with 5-fluorouracil have improved therapeutic response rates and overall survival by approximately 20-30\% and 4-6 months, respectively. However, this treatment can result in clinically significant adverse

\section{Biomed Central}


effects. In order to improve survival outcome and administer the most effective treatment, there is a requirement for more sensitive tumor markers than those currently available.

Matrix metalloproteinases (MMPs) are a family of zinc-dependent endopeptidases that mediate degradation of components of the extracellular matrix [2]. They are predominantly produced by stromal cells in response to the presence of tumor cells [3]. MMP-11 is a member of the MMP family that degrades ECM components and may play a central role in the enhancement of tumorinduced angiogenesis, cell migration, proliferation, apoptosis and connective tissue degradation [4,5]. MMP-11 differs from other MMPs, which are expressed as proenzymes and processed to active forms through proteolytic cleavage activated extracellularly, indicating that MMP11 could have a unique role in tumor development and progression [6]. Clinicopathological studies have demonstrated that MMP-11 is an important factor in tumor progression in various malignant tumors including pulmonary cancer [7], head and neck carcinoma [8,9] and breast carcinoma [10].

Previously, we demonstrated that MMP-11 serum levels were significantly higher in patients suffering from GC than in healthy individuals, and were correlated with recurrence of GC. Zhao et al [11] demonstrated that MMP-11 expression was associated with advancedstage and high-grade tumors, and correlated with increased expression of IGF-1. Min et al [12] suggested that IGF-1 receptor blockade could increase radiation and chemotherapy-induced apoptosis in mice. The aim of the present study was to investigate whether elevated MMP-11 expression could predict responses to frontline chemotherapy and prognosis of Chinese patients with advanced gastric carcinoma.

\section{Methods}

\section{Patient Selection}

Eighty-six patients with histopathologically confirmed advanced unresectable gastric adenocarcinoma (stages III c to IV) from March 2005 to February 2009 in Beijing Chao-Yang Hospital were studied retrospectively. Eligibility for the study required patients to have an Eastern Cooperative Oncology Group performance status of 0 to 2, and available plasma and measurable tumor focus evaluated by multi-detector spiral CT scanning. Patients had received front-line chemotherapy for at least three cycles and were observed for chemotherapy responses and survival outcomes. Tumors were staged according to the criteria of the American Joint Committee on Cancer (AJCC) TNM stage classification, sixth edition (2002) for Gastric Cancer. In accordance with the RECIST guidelines [13], response to therapy was categorized into four groups: complete response
$(\mathrm{CR})$, partial response (PR), stable disease (SD) and progression of disease (PD), with $\mathrm{CR}$ and $\mathrm{PR}$ confirmed for four weeks. For tumor response assessment, objective responses after three cycles of treatment were evaluated on the basis of computed tomography (CT) scans. Overall survival was calculated as the time from the beginning of chemotherapy to death or the last follow-up. The time to progression of disease was calculated from the date that chemotherapy began to the date of tumor progression. Twenty healthy volunteers were recruited as a control group. There was no evidence of malignancy on abdominal computed tomography examination of these individuals, and results of physical and laboratory examinations were normal. Individuals were excluded from the study if they did not give consent.

\section{Specimen Collection}

A total of 86 serum samples from patients with advanced gastric carcinoma and 20 samples from healthy individuals were obtained from the clinical laboratory. Serum samples from patients were collected in a fasting state early in the morning prior to front-line chemotherapy and after three cycles. Venous blood samples were collected in plain tubes, allowed to clot for one hour and centrifuged twice $(2500 \mathrm{~g})$ for 10 minutes at $4^{\circ} \mathrm{C}$ to obtain serum. The serum was removed, aliquoted and stored at $-70^{\circ} \mathrm{C}$ until required.

\section{MMP-11 Assay}

The concentration of MMP-11 protein was measured with a commercially available sandwich enzyme-linked immunoadsorbent assay kit based on monoclonal antibodies (Adlitteram Diagnostic Laboratories. Inc). Each sample was measured in duplicate. Serum samples from patients and control subjects were incubated in microtiter plates. Distilled or deionized water was added to the plates to be used as a blank control. Enzyme conjugate reagent $(50 \mu \mathrm{l})$ was added to each well, incubated for 60 min at $37^{\circ} \mathrm{C}$ and washed 5 times with distilled or deionized water. Finally, $50 \mu \mathrm{l}$ of color A and B reagents were added to each well and incubated for $15 \mathrm{~min}$. Stop solution $(50 \mu \mathrm{l})$ was placed in each well and mixed for 30 s. The color development was measured by absorbance at $450 \mathrm{~nm}$ using a microtiter plate reader. Accurate sample concentrations of MMP-11 were determined by comparing the specific absorbance with those obtained from the standards plotted on a standard curve.

\section{Statistical analysis}

Statistical analysis was carried out using the Chi-square test, Fisher's exact test, ANOVA and independent-samples t test. For all analyses, $\mathrm{p}<0.05$ was considered statistically significant. The $95 \%$ CI for hazard ratios and 
frequencies were calculated as exact CI. Receiver operating characteristic (ROC) curves were constructed by plotting sensitivity vs. (1-specificity), and the areas under the ROC curves (AUCs) were calculated. KaplanMeier curves were compared for survival using the standard log-rank test. To make further analyses with Kaplan-Meier curves possible, patients were split into two groups, one comprising patients with elevated MMP-11 protein and the other comprising patients without elevated MMP-11. The cut-off for this categorized variable was set at the 75th percentile of MMP-11 in the total group. SPSS software (version 15) was used for statistical analysis.

\section{Results}

\section{Patient Characteristics}

Eighty-six patients with advanced gastric carcinoma (stages III c to IV) who received palliative chemotherapy were included in the current analyses. Among these patients, 60 were male and 26 were female. The median age was 51 years (ranging from 50-56 years). Twenty three patients had well differentiated adenocarcinoma, 63 presented with poorly differentiated adenocarcinoma. Histological differentiation determined that 54 patients (62.8\%) had intestinal type adenocarcinoma, 20 (23.2\%) had mucinous carcinoma and signet-ring cell carcinoma was present in 12 patients (14.0\%). Clinical details are listed in Table 1. In the control group, 15 individuals were male and five were female. The median age was 40 years (ranging from 37-42 years).

\section{MMP-11 protein levels in sera of gastric carcinoma}

The serum levels of MMP-11 protein were significantly higher in patients with advanced gastric adenocarcinoma $(\mathrm{n}=86 ;$ median $=41.74 \mathrm{ng} / \mathrm{ml}$; range from 10.43 to $97.37 \mathrm{ng} / \mathrm{ml})$ than in controls $(\mathrm{n}=20$; median $=6.74$ $\mathrm{ng} / \mathrm{ml}$; range from 5.71 to $8.56 \mathrm{ng} / \mathrm{ml}$; $<0.001)$. Using ROC analysis, a cut-off level of MMP-11 protein at $14.38 \mathrm{ng} / \mathrm{ml}$ was associated with optimal sensitivity and specificity of $94.1 \%$ and $93.7 \%$, respectively, for diagnosis. ROC curve analysis is presented in Figure 1.

\section{Correlation between MMP-11 protein levels and clinicopathological characteristics}

The relationship between MMP-11 protein levels and patient clinicopathological parameters is summarized in Table 1. Serum levels of MMP-11 protein were not correlated with patient age, sex, disease stage and grade of differentiation. However, MMP-11 protein levels were significantly higher in patients suffering with lymph node metastasis, including 31 local and 4 distant lymph node metastases, compared with peritoneal seeding and internal organ metastasis $(\mathrm{P}=0.002$ and $\mathrm{P}=0.029$, respectively).

\section{Correlation between MMP-11 protein levels and chemotherapy response}

All patients had measurable tumor foci and received 5fluorouracil-based combination chemotherapy for at least three cycles (Table 2). PR was achieved in $44.2 \%$ $(38 / 86)$ of patients, $25.6 \%(22 / 86)$ had SD and $30.2 \%$ $(26 / 86)$ experienced PD with a median duration of six months and overall survival of ten months. MMP-11 serum levels were not correlated with the front-line chemotherapy response $(\mathrm{P}=0.182)$. Patients were divided into two groups according to MMP-11 levels (75th percentile or higher, and lower than the 75 th percentile). A total of 21 patients (24.4\%) had higher MMP-11 levels than the $62.09 \mathrm{ng} / \mathrm{ml}$ cut-off. Of these patients, $42.9 \%$ $(9 / 21)$ achieved PR, 28.6\% (6/21) had SD and 28.5\% (6/ $21)$ experienced PD. These results were similar to the 44.6\% (29/65) PR, 24.6\% (16/65) SD and 30.8\% (20/65) $\mathrm{PD}$ evident in the low MMP-11 level group $(\mathrm{P}=0.935)$. MMP-11 levels were differently altered in PR and PD. MMP-11 protein was lower than baseline in patients demonstrating PR (median $=45.15 \mathrm{ng} / \mathrm{ml}, 95 \% \mathrm{CI}$ : 35.79-62.09 vs. $44.12 \mathrm{ng} / \mathrm{ml}, 95 \% \mathrm{CI}$ : 34.32-56.52; $\mathrm{P}=$ $0.147)$. However, it showed an elevated trend in those with PD (median $=47.29 \mathrm{ng} / \mathrm{ml}, 95 \% \mathrm{CI}: 36.05-53.73$ vs. $50.52 \mathrm{ng} / \mathrm{ml}, 95 \% \mathrm{CI}: 37.74-54.22 ; \mathrm{P}=0.297$ ).

\section{Correlation between MMP-11 levels and survival}

The median follow-up time was 10.50 months (ranging from 9.07 to 12.94 months); the median TTP, OS and 1-year survival were six months, ten months and $40.0 \%$, respectively. The median TTP time for patients with low levels of MMP-11 was not significantly different from patients with high levels (median $=6.0$, range from 4.98 to 7.02 months vs. median $=5.0$ months, range from 3.28 to 6.72 months; $\mathrm{P}=0.178$, Figure 2). However, patients with low level MMP-11 protein had an higher median survival time and 1-year survival rate than those with high levels (11 vs. 8 months, $50.2 \%$ vs. $21.7 \%, \mathrm{P}=0.017$, Figure 3 ) in a multivariate analysis that considered MMP-11 level as an independent factor of $\mathrm{OS}$ in advanced gastric carcinoma $(\mathrm{HR}=2.618,95 \%$ CI 1.288-5.320, $\mathrm{P}=0.018$, Table 3).

\section{Discussion}

This study demonstrated that MMP-11 over-expression was consistently detected in advanced gastric adenocarcinoma. MMP-11 serum levels in 86 cases of advanced gastric adenocarcinoma were not associated with responses to 5-fluorouracil-containing chemotherapy and TTP as front-line chemotherapy. However, they correlated with lymph node status and mOS. These data suggest that MMP-11 could be involved in metastatic dissemination and be regarded as an independent prognostic factor of advanced gastric adenocarcinoma. 
Table 1 MMP-11 Levels and Clinical Characteristics

\begin{tabular}{|c|c|c|c|}
\hline \multirow[t]{2}{*}{ Clinical data } & \multirow[t]{2}{*}{ No. of Case (\%) } & MMP-11 level & \multirow[t]{2}{*}{$P^{- \text {-value }}$} \\
\hline & & Mean \pm SD $(\mathrm{ng} / \mathrm{ml})$ & \\
\hline NO. of patients & 86 & & \\
\hline \multicolumn{4}{|l|}{ Gender } \\
\hline Male & $60(69.8 \%)$ & $45.76 \pm 22.89$ & 0.200 \\
\hline Female & $26(30.2 \%)$ & $38.79 \pm 23.17$ & \\
\hline \multicolumn{4}{|l|}{ Age (yrs) } \\
\hline Median & $51(50-56)$ & & \\
\hline$<65$ & 63(73.3\%) & $43.40 \pm 22.76$ & 0.166 \\
\hline$\geq 65$ & $23(26.7 \%)$ & $50.79 \pm 21.96$ & \\
\hline \multicolumn{4}{|l|}{ Differentiation } \\
\hline G1, G2 & $23(26.7 \%)$ & $48.56 \pm 23.30$ & 0.235 \\
\hline G3 & 63(73.3\%) & $41.86 \pm 22.90$ & \\
\hline \multicolumn{4}{|l|}{ Histology } \\
\hline Intestinal type adenocarcinoma & $54(62.8 \%)$ & $44.22 \pm 23.92$ & \\
\hline Mucinous carcinoma & $20(23.2 \%)$ & $45.89 \pm 17.99$ & 0.527 \\
\hline Signet-ring cell carcinoma & $12(14.0 \%)$ & $53.44 \pm 23.80$ & \\
\hline \multicolumn{4}{|l|}{ ECOG } \\
\hline $0-1$ & 68(79.1\%) & $46.14 \pm 21.40$ & 0.610 \\
\hline 2 & 18(20.9\%) & $43.33 \pm 26.49$ & \\
\hline \multicolumn{4}{|l|}{ Disease stage } \\
\hline III C & $26(30.2 \%)$ & $43.22 \pm 31.02$ & 0.288 \\
\hline IV & $60(69.8 \%)$ & $48.45 \pm 23.57$ & \\
\hline \multicolumn{4}{|l|}{ Metastasis site } \\
\hline Lymph node & $35(40.7 \%)^{* \#}$ & $52.55 \pm 24.72$ & \\
\hline Peritoneum & $21(24.4 \%)^{\#}$ & $33.44 \pm 14.46$ & $0.006\left({ }^{*} 0.029,{ }^{\#} 0.002\right)$ \\
\hline Internal organs & $30(34.9 \%) *$ & $40.42 \pm 22.74$ & \\
\hline Chemotherapy cycles & 377 & & \\
\hline Median & $6.00(3.00-12.00)$ & & \\
\hline \multicolumn{4}{|l|}{$\mathrm{mTTP}(\mathrm{m})$} \\
\hline Median & $6.00(5.29-6.71)$ & & \\
\hline \multicolumn{4}{|l|}{$\mathrm{mOS}(\mathrm{m})$} \\
\hline Median & $10.00(8.51-11.50)$ & & \\
\hline \multicolumn{4}{|l|}{ Response } \\
\hline$P R$ & $38(44.2 \%)$ & $46.85 \pm 24.92$ & 0.182 \\
\hline SD & $22(25.6 \%)$ & $37.34 \pm 19.95$ & \\
\hline PD & $26(30.2 \%)$ & $48.97 \pm 20.23$ & \\
\hline
\end{tabular}

Abbreviations: PR, partial response; SD, stable disease; PD, progression of disease. Analysis of the difference between groups using analysis of variance (ANOVA). Where differences were identified, further analysis (between pairs of groups, with respective pairs for each molecule marked with *and *) was performed using Scheffe $(95 \%$ confidence interval $(\mathrm{Cl}))$

Despite improvements in surgical techniques and the development of new chemotherapy regimes, gastric carcinoma remains the third leading cause of cancer-related deaths in China [14]. Previously, we demonstrated that MMP-11 was a cancer-related protein and its overexpression was consistently confirmed at mRNA and protein levels in primary gastric adenocarcinoma tumors compared with matched normal tissues. Currently, the impact of MMP-11 on advanced gastric adenocarcinoma is uncertain. The aim of the study was to evaluate the associations between the expression of MMP-11 protein in serum and response to front-line chemotherapy and prognosis in advanced gastric adenocarcinoma. The results demonstrate that serum MMP-11 levels are not correlated with response to front-line chemotherapy, but are correlated with lymph node status and mOS in patients with advanced gastric adenocarcinoma.

MMPs have a broad spectrum of proteolytic activities towards extracellular matrix (ECM) components, and are believed to be involved in several biological processes 


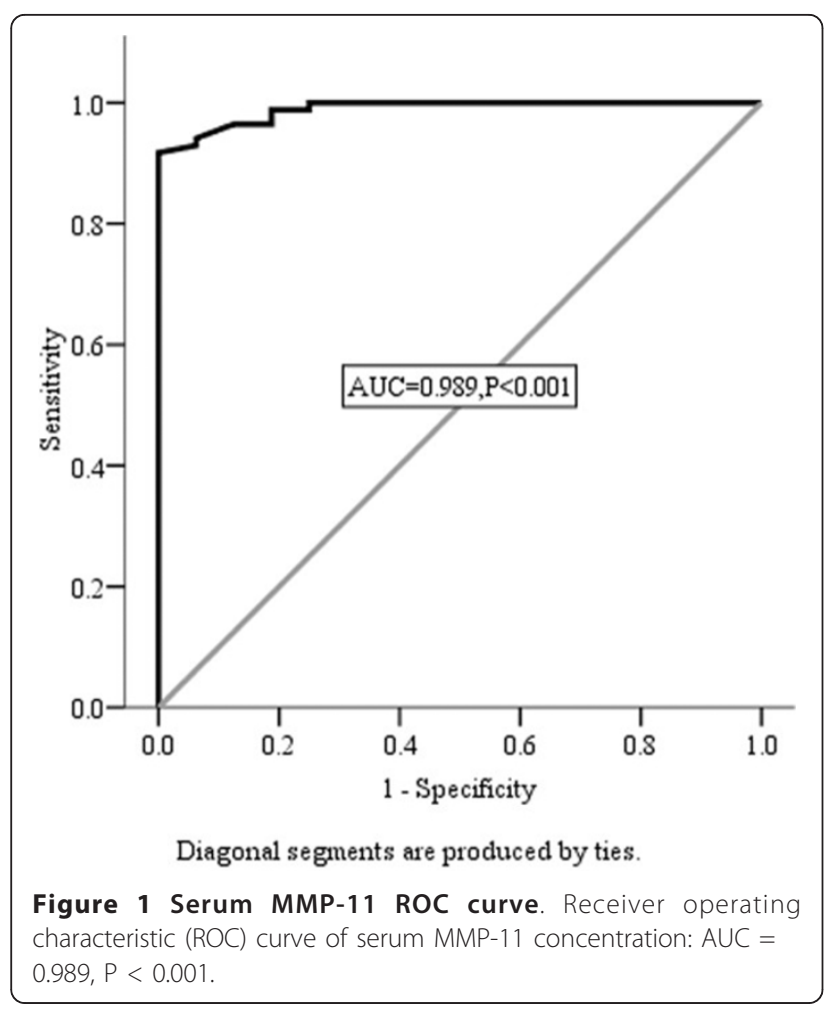

including embryo implantation and morphogenesis, cell migration, metastasis, tumor invasion and wound healing $[15,16]$. MMP-11 over-expression has been demonstrated in human cancers including oral cancer $[17,18]$, desmoid tumors [19], non-small cell lung cancer [20] and esophageal adenocarcinoma [21]. Furthermore, increased MMP11 gene expression is correlated with increased aggressiveness of tumors and a poor clinical outcome [22,23]. Clinical trials have demonstrated that a high level of MMP-11 expression is correlated with a lower survival rate among patients with breast, non-small cell lung cancer and colon cancer $[24,25]$. Deng et al [6] reported that the BGC823 cell-line silenced MMP-11 expression and significantly inhibited cell proliferation and colony formation in soft agar medium and tumorigenicity in nude mice. The same authors also demonstrated that MMP-11 promoted the proliferation, invasion and tumorigenicity of the AGS cell line. Such experimental evidence has provided a causative role for MMP-11 protein during tumor progression. This study is the first to identify a correlation between MMP-

Table 2 Chemotherapy Regimens Used in AGC

\begin{tabular}{cc}
\hline Chemotherapy regimen & Number of patients \\
\hline Paclitaxel, cisplatin, 5-fluorouracil & 37 \\
Paclitaxel, 5-fluorouracil & 21 \\
Oxaliplatin, 5-fluorouracil & 18 \\
Docetaxel, 5-fluorouracil & 10 \\
\hline
\end{tabular}

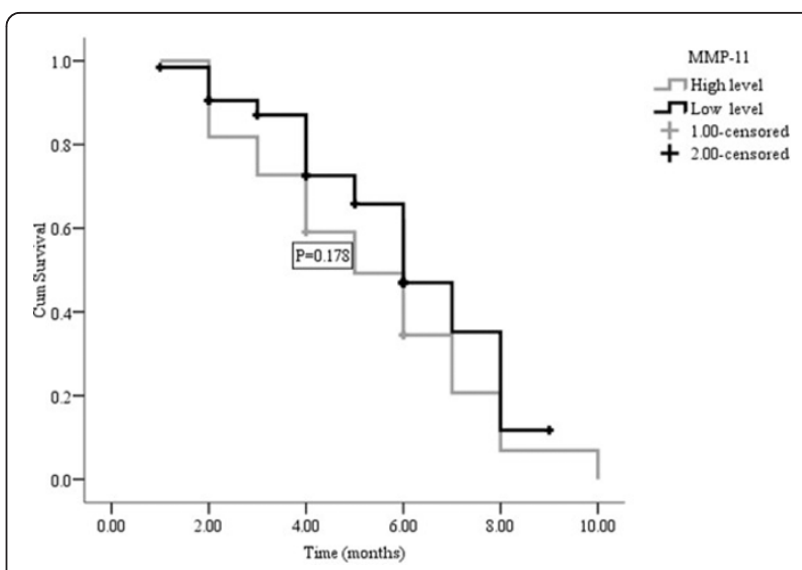

Figure 2 TTP curves of high level MMP-11 compared with low level MMP-11.

11 expression and outcome in advanced gastric adenocarcinoma patients. In this study, MMP-11 protein levels appeared to correlate with invasion potential and high levels were related to the extent of lymph node metastasis in GC $(\mathrm{P}=0.006)$, similar to data reported for other malignancies [26]. Moreover, this study demonstrates that patients with high level MMP-11 expression had a shorter survival time than patients with low levels of MMP-11. In other words, the findings indicate that MMP-11 protein is an independent prognostic factor for patients with advanced gastric adenocarcinoma. As has been reported previously in breast and head and neck cancer, there were no obvious associations among the degree of tumor differentiation, MMP-11 protein level, sex and age.

There was no statistical difference between MMP-11 levels with mTTP and chemotherapy response. Potential reasons for this could be: (1) there were no differences in terms of the effects of MMP-11 on MTTP and chemotherapy response in advanced gastric adenocarcinoma;

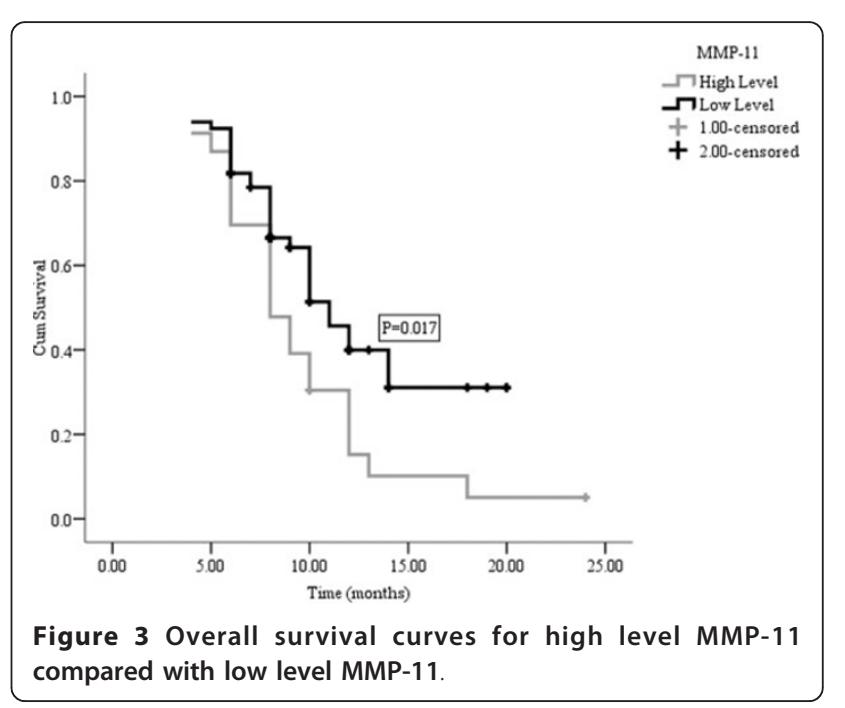


Table 3 Association between Clinical Features and Survival Using Multivariate Analysis

\begin{tabular}{|c|c|c|c|c|}
\hline \multirow[t]{2}{*}{ Parameter } & & \multicolumn{3}{|c|}{ Multivariate Analysis } \\
\hline & & $P^{\text {-value }}$ & HR & $95 \% \mathrm{Cl}$ \\
\hline \multirow[t]{2}{*}{ Gender } & Male & 0.622 & 1.199 & $0.582-2.473$ \\
\hline & Female & & 1 & \\
\hline \multirow[t]{2}{*}{ Age } & $<65$ & 0.215 & 1.569 & 0.770-3.199 \\
\hline & $\geq 65$ & & 1 & \\
\hline \multirow[t]{3}{*}{ Histology } & Intestinal type adenocarcinoma & 0.150 & 0.415 & $0.126-1.373$ \\
\hline & Mucinous carcinoma & 0.588 & 0.752 & $0.268-2.106$ \\
\hline & Signet-ring cell & & 1 & \\
\hline \multirow[t]{2}{*}{ Differentiation } & G1, G2 & 0.492 & 0.761 & $0.350-1.658$ \\
\hline & G3 & & 1 & \\
\hline \multirow[t]{2}{*}{ Metastatic site } & Dissemination & 0.516 & 1.387 & $0.578-3.437$ \\
\hline & Local & & 1 & \\
\hline \multirow[t]{2}{*}{ Stage of disease } & $\| I I C$ & 0.025 & 0.273 & $0.088-0.849$ \\
\hline & IV & & 1 & \\
\hline \multirow[t]{2}{*}{ MMP-11 protein level } & High level & 0.018 & 2.618 & $1.288-5.320$ \\
\hline & Low level & & 1 & \\
\hline
\end{tabular}

Abbreviation: $\mathrm{HR}$, hazard ratio; $\mathrm{Cl}$, confidence interval.

(2) the number of cases studied in the current research was not large enough. The OS in the present study was different from the results reported for the V325 trial [27]. Possible explanations include the fact that this was a retrospective study; several factors could influence survival. The chemotherapy regimens used in the present study differed in some ways from that used in the V325 trial, which could affect OS.

\section{Conclusions}

This study suggests that serum levels of MMP-11 protein in Chinese patients with advanced GC are not associated with responses to front-line chemotherapy. However, MMP-11 could have a role in lymph node metastasis and could potentially be an independent factor for prognosis.

\section{Acknowledgements}

My deepest gratitude goes to my supervisor, Professor Lin Shen, for her constant encouragement and guidance.

\section{Author details}

${ }^{1}$ Department of Oncology, Beijing Chao-Yang Hospital affiliated with Capital Medical University, 8\# Baijiazhuang Road, Beijing, China. ${ }^{2}$ Department of Clinical Chemical Examination, Beijing Chao-Yang Hospital affiliated with Capital Medical University, 8\# Baijiazhuang Road, Beijing, China.

\section{Authors' contributions}

Dong Yan analyzed and interpreted MMP-11 expression in advanced gastric adenocarcinoma, and was a major contributor to writing of the manuscript. Jin-Wei Liu performed the examination of MMP-11. All authors read and approved the final manuscript.

\section{Competing interests}

I certify that my affiliations with, or financial involvement in, any organization or entity with a financial interest in or financial conflict with the subject matter or materials discussed in this manuscript, within the past five years and foreseeable future, are disclosed.
Received: 29 April 2010 Accepted: 24 April 2011

Published: 24 April 2011

\section{References}

1. Lustosa SA, Saconato H, Atallah AN, Lopes Filho Gde J, Matos D: Impact of extended lymphadenectomy on morbidity, mortality, recurrence and 5year survival after gastrectomy for cancer: Meta-analysis of randomized clinical trials. Acta Cir Bras 2008, 23:520-530.

2. Nelson AR, Fingleton B, Rothenberg ML, Matrisian LM: Matrix metalloproteinases: biologic activity and clinical implications. J Clin Oncol 2000, 18:1135-1149.

3. Drác P, Klein J, Tichý T, Kolek V, Skarda J: Prognostic impact of matrix metalloproteinases 2,9 and 11 in stromal cells stage I non-small cell lung cancer. Cas Lek Cesk 2007, 146:45-47, [In Czech].

4. Vazquez-Ortiz G, Pina-Sanchez P, Vazquez K, Duenas A, Taja L, Mendoza P, Garcia JA, Salcedo M: Overexpression of cathepsin F, matrix metalloproteinases 11 and 12 in cervical cancer. BMC cancer 2005, 5:68.

5. Bartolomé RA, Ferreiro S, Miquilena-Colina ME, Martínez-Prats L, SotoMontenegro ML, García-Bernal D, Vaquero JJ, Agami R, Delgado R, Desco M, Sánchez-Mateos P, Teixidó J: The chemokine receptor CXCR4 and the metalloproteinase MT1-MMP are mutually required during melanoma metastasis to lungs. Am J Pathol 2009, 174:602-612.

6. Deng H, Guo RF, Li WM, Zhao M, Lu YY: Matrix metalloproteinase 11 depletion inhibits cell proliferation in gastric cancer cells. Biochem Biophys Res Commun 2005, 326:274-281.

7. Kren L, Goncharuk VN, Krenová Z, Stratil D, Hermanová M, Skricková J, Sheehan CE, Ross JS: Expression of matrix metalloproteinases 3, 10 and 11 (stromelysins 1, 2 and 3) and matrix metalloproteinase 7 (matrilysin) by cancer cells in non-small cell lung neoplasms: Clinicopathologic studies. Cesk Patol 2006, 42:16-19.

8. Thorns V, Walter GF, Thorns C: Expression of MMP-2, MMP-7, MMP-9, MMP-10 and MMP-11 in human astrocytic and oligodendroglial gliomas. Anticancer Res 2003, 23:3937-3944.

9. Wasenius VM, Hemmer S, Kettunen E, Knuutila S, Franssila K, Joensuu H: Hepatocyte growth factor receptor, matrix metalloproteinase-11, tissue inhibitor of metalloproteinase-1, and fibronectin are up-regulated in papillary thyroid carcinoma: a cDNA and tissue microarray study. Clin Cancer Res 2003, 9:68-75.

10. Mellick AS, Blackmore D, Weinstein SR, Griffiths LR: An assessment of MMP and TIMP gene expression in cell lines and stroma tumour differences in microdissected breast cancer biopsies. Tumour Biol 2003, 24:258-270.

11. Zhao ZS, Chu YQ, Ye ZY, Wang YY, Tao HQ: Overexpression of matrix metalloproteinase 11 in human gastric carcinoma and its clinicopathologic significance. Hum Pathol 2010, 41:686-696. 
12. Min $Y$, Adachi $Y$, Yamamoto H, Imsumran A, Arimura $Y$, Endo $T$, Hinoda $Y$, Lee CT, Nadaf S, Carbone DP, Imai K: Insulin-like growth factor I receptor blockade enhances chemotherapy and radiation responses and inhibits tumour growth in human gastric cancer xenografts. Gut 2005, 54:591-600.

13. Tsuchida $Y$, Therasse $P$ : Response evaluation criteria in solid tumors (RECIST): new guidelines. Med Pediatr Oncol 2001, 37:1-3.

14. Li H, Diao YT, Ma JX, Xu AQ, Li HQ, Ma Q, Yin C, Cui J, Cui YC: Time trends on the prevalence of cancer during 1970-2005 in Shandong province. Zhonghua Liu Xing Bing Xue Za Zhi 2009, 30:592-595, [In Chinese].

15. Pei D: Matrix metalloproteinases target protease-activated receptors on the tumor cell surface. Cancer Cell 2005, 7:207-208.

16. Mañes S, Mira E, Barbacid MM, Ciprés A, Fernández-Resa P, Buesa JM, Mérida I, Aracil M, Márquez G, Martínez-A C: Identification of insulin-like growth factor-binding protein-1 as a potential physiological substrate for human stromelysin-3. J Biol Chem 1997, 272:25706-25712.

17. Soni S, Mathur M, Shukla NK, Deo SV, Ralhan R: Stromelysin-3 expression is an early event in human oral tumorigenesis. Int J Cancer 2003, 107:309-316

18. Arora S, Kaur J, Sharma C, Mathur M, Bahadur S, Shukla NK, Deo SV, Ralhan R: Stromelysin 3, Ets-1, and vascular endothelial growth factor expression in oral precancerous and cancerous lesions: correlation with microvessel density, progression, and prognosis. Clin Cancer Res 2005, 11:2272-2284.

19. Denys H, De Wever O, Nusgens B, Kong Y, Sciot R, Le AT, Van Dam K, Jadidizadeh A, Tejpar S, Mareel M, Alman B, Cassiman JJ: Invasion and MMP expression profile in desmoid tumours. Br J Cancer 2004, 90:1443-1449

20. Kettunen $E$, Anttila $S$, Seppänen JK, Karjalainen $A$, Edgren $H$, Lindström I, Salovaara R, Nissén AM, Salo J, Mattson K, Hollmén J, Knuutila S, Wikman H: Differentially expressed genes in nonsmall cell lung cancer: expression profiling of cancer-related genes in squamous cell lung cancer. Cancer Genet Cytogenet 2004, 149:98-106.

21. Hourihan RN, O'Sullivan GC, Morgan JG: Transcriptional gene expression profiles of oesophageal adenocarcinoma and normal oesophageal tissues. Anticancer Res 2003, 23:161-165.

22. Boulay A, Masson R, Chenard MP, El Fahime M, Cassard L, Bellocq JP, Sautès-Fridman C, Basset P, Rio MC: High cancer cell death in syngeneic tumors developed in host mice deficient for the stromelysin-3 matrix metalloproteinase. Cancer Res 2001, 61:2189-2193.

23. Andarawewa KL, Boulay A, Masson R, Mathelin C, Stoll I, Tomasetto C, Chenard MP, Gintz M, Bellocq JP, Rio MCL: Dual stromelysin-3 function during natural mouse mammary tumor virus-ras tumor progression. Cancer Res 2003, 63:5844-5849.

24. Têtu B, Trudel D, Wang CS: Proteases by reactive stromal cells in cancer: an attractive therapeutic target. Bull Cancer 2006, 93:944-948, [In French].

25. Cheng CW, Yu JC, Wang HW, Huang CS, Shieh JC, Fu YP, Chang CW, Wu PE, Shen CY: The clinical implications of MMP-11 and CK-20 expression in human breast cancer. Clin Chim Acta 2010, 411:234-241.

26. Kren L, Goncharuk VN, Krenová Z, Stratil D, Hermanová M, Skricková J, Sheehan CE, Ross JS: Expression of matrix metalloproteinases 3, 10 and 11 (stromelysins 1, 2 and 3) and matrix metalloproteinase 7 (matrilysin) by cancer cells in non-small cell lung neoplasms: Clinicopathologic studies. Cesk Patol 2006, 42:16-19.

27. Ajani JA, Moiseyenko VM, Tjulandin S, Majlis A, Constenla M, Boni C, Rodrigues A, Fodor M, Chao Y, Voznyi E, Awad L, Van Cutsem E: Quality of life with docetaxel plus cisplatin and fluorouracil compared with cisplatin and fluorouracil from a phase III trial for advanced gastric or gastroesophageal adenocarcinoma: the V-325 Study Group. J Clin Oncol 2007, 25:3210-3216.

\section{Pre-publication history}

The pre-publication history for this paper can be accessed here: http://www.biomedcentral.com/1471-2407/11/151/prepub

doi:10.1186/1471-2407-11-151

Cite this article as: Yan et al:: Serum levels of MMP-11 correlate with clinical outcome in Chinese patients with advanced gastric adenocarcinoma. BMC Cancer 2011 11:151.

\section{Submit your next manuscript to BioMed Central and take full advantage of:}

- Convenient online submission

- Thorough peer review

- No space constraints or color figure charges

- Immediate publication on acceptance

- Inclusion in PubMed, CAS, Scopus and Google Scholar

- Research which is freely available for redistribution

Submit your manuscript at www.biomedcentral.com/submit
Biomed Central 